\title{
The Qârusuk dykes: post-Nûk, pre-Qôrqut granitoid magmatism in the Godthåb region, southern West Greenland
}

\author{
V. R. McGregor, D. Bridgwater \& A. P. Nutman
}

\begin{abstract}
The Qârusuk dykes are minor intrusions of granitic and trondhjemitic gneiss emplaced in the Godthåb region between 2700 and $2600 \mathrm{Ma}$ ago. They post-date the Nûk gneisses and their subsequent regional deformation and metamorphism but pre-date the essentially post-tectonic Qôrqut granite complex. They are associated in time and commonly in place with intense ductile deformation concentrated in distinct belts along which there was considerable movement of fluids accompanied by retrogression of earlier mineral assemblages. Outside the Godthåb district dykes of similar character post-date the regional c. $2800 \mathrm{Ma}$ granulite facies metamorphism. The dykes are siliceous with low $\mathrm{Fe}^{t}+$ $\mathrm{MgO}$ and high $\mathrm{Na}_{2} \mathrm{O}+\mathrm{K}_{2} \mathrm{O}$. Variation in $\mathrm{Na}_{2} \mathrm{O} / \mathrm{K}_{2} \mathrm{O}$ is at least in part attributed to exchange between magma and percolating fluids. Non-magmatic controls are thought to affect trace element (including REE) and isotopic compositions. The overall chemical character is consistent with derivation by partial melting of sialic rocks associated with the influx of hydrous fluids associated with shear belt formation.
\end{abstract}

\section{Introduction}

In this paper we introduce the term Qârusuk dykes for minor intrusions of granitic and trondhjemitic aplite and pegmatite that were emplaced in the Godthåb region c. 2700-2600 Ma ago. They post-date the emplacement of the voluminous Nûk gneisses (McGregor, $1973 ; 1979)$ and subsequent folding and metamorphism that in parts of the region culminated in granulite facies conditions c. 2800 Ma ago (Black et al., 1973; Pidgeon \& Kalsbeek, 1978), but pre-date the emplacement of the essentially post-tectonic Qôrqut granite complex (McGregor, 1973; Brown et al., 1981). Emplacement of the Qârusuk dykes appears to have been contemporaneous with the formation of linear belts of intense ductile deformation and with extensive retrogression from granulite to amphibolite facies mineral assemblages (Table 1).

The quartzo-feldspathic gneisses of the Godthåb region were divided into two suites on the basis of presence or absence of abundant basic dykes (Ameralik dykes) or amphibolites derived from basic dykes (McGregor, 1973; 1979). The older suite, the Amîtsoq gneisses, has yielded ages in the range 3800-3500 Ma (see Bridgwater et al., 1976, and McGregor, 1979 , for references). The term Nûk gneisses was used for all quartzo-feldspathic gneisses (i.e. deformed granitoid rocks) in the Godthåb region that do not contain Ameralik dykes. 


\section{Table 1. Revised chronology of the Godthåb - outer Godthåbsfjord region}

(11) Metamorphism at 1500-1600 Ma that caused partial recrystallisation and is recorded in $\mathrm{Rb}-\mathrm{Sr}$ mineral ages. Simple shear deformation producing faults predominantly with a NE-trend, along which there was retrogression to greenschist facies. Intrusion of basic dykes before and associated with faulting.

(10) Granites and pegmatites intruded in a NNE-SSW trending belt to form the Qôrqut granite complex: 2530 Ma.

(9) Ductile deformation concentrated in linear belts. Thermal distrubance and influx of $\mathrm{H}_{2} \mathrm{O}$-rich fluids caused retrogression from granulite facies to amphibolite facies in some areas. Intrusion of minor granitoid dykes and pegmatites - Qârusuk dykes: c. 2600-2700 Ma.

(8) Metamorphism reaching granulite facies in parts of the area: c. $2800 \mathrm{Ma}$.

(7) Thrusting, syntectonic intrusion of very voluminous tonalitic-granodioritic-trondhjemitic magmas - Nûk gneisses - within the period 3100-2900 Ma, accompanied and followed by polyphase deformation.

(6) Intrusion of layered anorthosite-leucogabbro complex(es).

(5) Deposition of detrital sediments, dominantly submarine extrusion of mafic and ultramafic volcanics and related shallow intrusions - Malene supracrustal rocks.

(4) Intrusion of basic dyke swarm(s) - Ameralik dykes.

(3) Metamorphism culminating in granulite facies conditions in the south of the region $-c .3600 \mathrm{Ma}$. Intrusion of Fe-rich granitic rocks and associated subordinate ferrodiorites, granites and trondhjemites - Amîtsoq iron-rich association.

(2) Intrusion (syntectonic?) of voluminous tonalitic-granodioritic magmas - Amîtsoq grey gneisses - c. $3700 \mathrm{Ma}$. Injection of pegmatite and granitic sheets, deformation and metamorphism up to amphibolite facies.

(1) Extrusion of mafic and felsic volcanic rocks. Deposition of chemical sediments and subordinate felsic and pelitic sediments, intrusion of mafic and ultramafic sheets - Akilia association. Correlated with the Isua supracrustal rocks $-c$. $3800 \mathrm{Ma}$.

The least metamorphosed Nûk gneisses, on south-eastern Bjørneøen, have yielded U-Pb zircon and Rb-Sr whole rock isochron ages of 3090-2950 Ma (Taylor et al., 1980; Baadsgaard \& McGregor, 1981). Younger ages reported for Nûk gneisses are thought to reflect metamorphic disturbance of the isotopic systems (Karlsbeek \& Pidgeon, 1980; Baadsgaard \& McGregor, 1981) or to be due to the use of mixed suites of rocks that include a post-Nûk component. The type Nûk gneisses thus pre-date granulite facies metamorphism of the surrounding areas.

The type Nûk gneisses are dominantly tonalitic to granodioritic in composition with smaller amounts of early dioritic and late trondhjemitic phases. Granitic (s.s.) compositions are uncommon and in general the suite is characterises by high $\mathrm{Na} / \mathrm{K}$ ratios. The Nûk magmas were intruded syntectonically during a period of predominantly sub-horizontal movement (McGregor, 1979; Bridgwater et al., 1974). Earlier phases were commonly deformed before being intruded by later phases.

It is now apparent that some gneisses in the Godthåb region post-date the granulite facies metamorphism, but pre-date the essentially undeformed rocks of the Qôrqut granite complex. Since these late gneisses were generated and intruded under conditions different from the type Nûk gneisses and differ from them in chemistry (see below), we propose that they no longer be included under the term Nûk gneisses, and introduce the term Qârusuk dykes for minor gneissic intrusions in the central and southern parts of the Godthåb region. 


\section{The type Qârusuk dykes}

Polyphase migmatic Nûk gneisses on the south-eastern corner of Bjørneøen between Sidtdlisit nûat and Qârusuk $\left(64^{\circ} 21^{\prime} 40^{\prime \prime} \mathrm{W}\right)$ are cut by irregular dykes of fine-grained, greenish-grey aplite which range in thickness from a few centimetres to several metres. A number of these bodies have been figured in earlier papers (McGregor, 1973, figs 12 \& 13; McGregor, 1979, fig 3). One of the aplites has yielded a zircon concordia/discordia intersection age of $2660 \mathrm{Ma}$ (Baadsgaard \& McGregor, 1981). The term Qârusuk dykes is introduced here for these rocks and for leucocratic dykes elsewhere in the Godthåb region that can be shown to have the same general age and tectonic setting as the type rocks.

The Qârusuk dykes on south-eastern Bjørneøen have finer grain sizes than the enclosing Nûk gneisses. Where least deformed, their contacts can be seen to have been originally irregular. Steps in the dyke contacts extend out into the country rocks as shear zones, showing that the country rocks were brittle when the dykes were intruded. Where such stepped contacts are deformed, they can resemble cuspate contacts of the type seen in some dykes intruded into hot, relatively ductile country rocks (McGregor, 1973, fig. 13). Cataclastic structures have been noted along and within some dyke margins. Some dykes contain quartz segregations that resemble tension gashes and that appear to have been formed during the same structural episode which controlled intrusion of the dykes. All these features indicate that many of the dykes were intruded along active shear fractures. The marginal parts of several of the least deformed dykes have a bleached appearance.

South-eastern Bjørneøen lies within a metamorphic low (Dymek, 1978) and the fine-grained nature of the rocks there compared with many other parts of the region suggests that the area here may represent a relatively higher crustal level. White muscovite-garnet-bearing pegmatites, many of them several tens of metres thick, are a prominent feature of the geology of Bjørenøen and Sadelø. Locally they contain beryl and tourmaline. Small pegmatites of this type are closely associated with Qârusuk dykes (McGregor, 1973, fig. 12), suggesting that the aplites and pegmatites are contemporaneous. James (1975) noted that these pegmatites post-date the formation of the main deformational fabric in the Nûk gneisses, but are affected by later open folds.

Late granitic dykes that cut Nûk gneisses with considerable discordance can be seen for some $4 \mathrm{~km}$ along the south coast of Bjørneøen west of Qârusuk. They probably include correlatives of the type Qârusuk dykes, but their separation from the Nûk gneisses is more difficult because of late Archaean deformation that reduces the discordant nature of the contacts and because of increase in grain size reflecting stronger metamorphic recrystallisation. One irregular late body of fine-grained gneiss $c .1 \mathrm{~km}$ north-west of Qârusuk was identified in the field as a Qârusuk dyke, but a zircon date showed it to be of Nûk age (Baadsgaard \& McGregor, 1981, sample 248079). Clearly discordant, late, leucocratic dykes can be seen to become thin layers completely concordant with their strongly banded country rocks where they cross into zones of intense ductile shear. On the south-western part of Bjørneøen the late leucocratic dykes are so intensely deformed that they are rarely distinguishable from the enclosing Nûk gneisses. This part of Bjørneøen lies within a linear belt of intense ductile deformation that extends south-south-west through south-western Sadelø, the Godthåb - Store Malene peninsula and the islands to the south. Recognition of Qârusuk dykes is thus not always possible in field criteria alone in areas where there is no major metamorphic or structural event separating them from the Nûk gneisses. 


\section{Qârusuk dykes elsewhere in the Godthåb region}

No systematic search has been made for Qârusuk dykes, but comparable rocks have been noted at a number of localities and appear to be a widespread, although volumetrically minor component of the coastal region. Layered gneisses at the head of Ujaragssuit pâvat in inner Godthåbsfjord were collected by D.B. and V.R.M. in 1972 as Nûk gneisses because they lack amphibolites of Ameralik-dyke type. They have, however, chemical and $\mathrm{Rb}-\mathrm{Sr}$ and $\mathrm{Pb}-\mathrm{Pb}$ isotopic characters which are more like the Qârusuk dykes than the type Nûk gneisses (see Tables 1 \& 3). Further field work (Brewer et al., 1983; Nutman, 1982; Coe \& Robertson, 1982) as well as new isotopic information (Robertson, 1983) has shown that late Archaean granitic (s.s.) rocks are abundant in inner Godthåbsfjord.

(1) Qeqertat $\left(64^{\circ} 20^{\prime} 25^{\prime \prime} \mathrm{N}, 51^{\circ} 35^{\prime} 50^{\prime \prime} \mathrm{W}\right)$. The western margin of the Godthåb town south-west Bjørneøen deformation belt passes through the western island of Qeqertat, south-west of Bjørneøen. West of the deformation belt very pale, homogeneous Nûk gneisses with a faint sub-vertical foliation are cut by many irregular grey dykes similar in appearance and contact features to the type Qârusuk aplitic dykes, but more coarse grained. Grey dykes at the margin of the deformation belt were intruded after much of the deformation, but were affected by later movement in the belt.

(2) Godthåb town $\left(64^{\circ} 10^{\prime} \mathrm{N}, 51^{\circ} 45^{\prime} \mathrm{W}\right)$. Several thin, strongly-deformed aplite and pegmatite sheets of Qârusuk-dyke type were noted on the point just south-west of the old Herrnhut mission. Some of the sheets are composite with aplitic and pegmatitic parts. Like the grey dykes on Qeqertat they appear to post-date part of the linear belt deformation.

Strongly discordant composite aplite-pegmatite sheets cut Nûk gneisses on the point between Dronning Ingrids Hospital and Entreprenørdalen. These post-data the linear belt deformation, but were emplaced in gently dipping shear fractures and have a weak fabric. No other rocks of Qârusuk dyke type were seen along this well-exposed section of coast.

(3) Simiutâ $\left(64^{\circ} 2^{\prime} 32^{\prime \prime} \mathrm{N}, 51^{\circ} 38^{\prime} 10^{\prime \prime} \mathrm{W}\right)$. Coarse-grained Amitsoq gneisses in the south-western corner of Simiutâ, an island at the mouth of Ameralik, are cut by deformed gneiss sheets sub-parallel to the regional late-Archaean NNE-trending structure. Unpublished $\mathrm{Rb}$-Sr whole isotopic data (S. Moorbath, personal communication) show considerable scatter, but are consistent with a post-Nûk age of emplacement of these dykes. Their relation to the deformation suggests a pre Qôrqut period of emplacement and we therefore group them with the Qârusuk dykes which they resemble chemically.

The type Amîtsoq gneisses along the coast of the outher part of Ameralik are cut by many sheets of homogeneous pale gneiss that post-date the Ameralik dykes. Many of these late gneiss sheets may be Qârusuk dykes.

(4) Kangimut sangmissoq $\left(64^{\circ} 6^{\prime} 20^{\prime \prime} \mathrm{N}, 50^{\circ} 55^{\prime} 30^{\prime \prime} \mathrm{W}\right)$. At the eastern end of Kangimut sangmissoq, a peninsula on the south coast of the middle section of Ameralik, Amitsoq gneisses that have been retrogressed from granulite facies are cut by thin dykes that clearly post-date the granulite facies metamorphism. The late dykes vary in thickness from less than a centimetre to $c$. 10 metres. Almost all follow shear fractures (McGregor, 1979, fig. 9). Many of the dykes are composite with pegmatic and aplitic fractions. Some are strongly 
inhomogeneous, pegmatite-layered gneisses. The gneissic structure of these sheets post-dates structures in the wall rock and is thought to be the result of filter-pressing action caused by movement of the dyke walls as the magma was crystallising.

Four specimens from the late dykes give a $\mathrm{Rb} / \mathrm{Sr}$ whole rocks isochron age of $2680 \pm 160$ Ma with an initial ${ }^{87} \mathrm{Sr} /{ }^{86} \mathrm{Sr}$ ratio of $0.7045 \pm 0.0010$ (S. Moorbath \& P. Taylor, personal communication).

At the southern end of the same outcrop the retrogressed gneisses are cut by sub-horizontal sheets of underformed granitic material. These are geochemically identical to the syntectonic sheets described above (Table 1).

(5) Nipinganeq $\left(64^{\circ} 7^{\prime} 30^{\prime \prime} \mathrm{N}, 51^{\circ} 3^{\prime} 40^{\prime \prime} \mathrm{W}\right)$. Roberts (1979) described granitic dykes (Nipinganeq granites) that cut an early Nâk tonalite in the core of a broad synform on the north coast of Ameralik opposite Kangimut sangmissoq. These dykes, one of which was figured by McGregor (1979, fig. 8), are very similar to the late dykes at Kangimut sangmissoq. They are commonly composite with pegmatitic margins and foliated gneissic cores. Many of them were intruded along active shear fractures. The dykes post-date granulite facies metamorphism of the tonalite, but are affected by strong deformation in linear belts that mark the limbs of the synform.

Roberts (1979) obtained a six-point $\mathrm{Rb} / \mathrm{Sr}$ whole rock isochron age of $2692 \pm 62 \mathrm{Ma}$ in the Nipinganeq granites and concluded in the basis of their initial ${ }^{87} \mathrm{Sr} /{ }^{86} \mathrm{Sr}$ ratio of $0.7060 \pm$ 0.0015 that they were derived from a crustal source. Both trondhjemitic and granitic varieties occur.

\section{Late Archaean granitoid magmatism in other areas}

(1) Amitsorssuaq $\left(63^{\circ} 48^{\prime} 30^{\prime \prime} \mathrm{N}, 51^{\circ} 4^{\prime} \mathrm{W}\right)$. In the northern part of Amitsorssuaq, a small branch on the north side of Buksefjorden, Amitsoq gneisses, recognised by the presence of abundant Ameralik dykes, have been metamorphosed by the regional c. 2800 Ma granulite facies event and then retrogressed to amphibolite facies assemblages. They are cut by sheets of homogeneous white gneiss that post-date the granulite facies metamorphism.

(2) Between Buksefjorden and Taserssuatsiat. Thin leucocratic sheets that post-date the late Archaean granulite facies metamorphism occur sporadically in this area. Previously they were described as a late, minor phase of the Nûk magmatism (Compton, personal communication, 1975). The granitic sheets, usually less than 1 metre thick, are discordant to the compositional layering in the country rocks and are commonly little-deformed. Many of the sheets follow shear fractures which in some cases show evidence of further movement after the sheets were emplaced. The sheet margins are commonly marked by biotite-rich selvages and lenses of pegmatite. Their chronological position relative to the granulite facies metamorphism and their intrusive form shows that they belong to the same general period of emplacement as the Qârusuk dykes and their chemistry is comparable to that of the rocks from the type locality.

(3) Fiskenasset - Frederikshäb Isblink area. The late Archaean plutonic history of the Fiskenæsset area is complex (Kalsbeek \& Myers, 1973; Bridgwater et al., 1976). The re- 
gional granulite facies metamorphism dated by $\mathrm{U}-\mathrm{Pb}$ on zircons at $2795 \pm 11 \mathrm{Ma}$ (Pidgeon \& Kalsbeek, 1978) provides a useful datum to separate possible correlatives of the type Nûk gneisses from younger rocks comparable an age and geological setting on the Qârusuk dykes. Myers (1973, 1976) and Bridgwater et al. (1976) briefly describe the Qángertoq gneisses, numerous small irregular intrusions cutting both the regionally deformed gneisses and the syn-granulite facies Ilivertalik granite. Foliated muscovite granite sheets emplaced during or affected by late Archaean deformation of the Ravns Storø supracrustal belt (Andersen \& Friend, 1973) give a U-Pb zircon concordia intercept age of $2660 \pm 20 \mathrm{Ma}$ (Pidgeon \& Karlsbeek, 1978) similar to the U-Pb age obtained from the type Qârusuk dykes (Baadsgaard \& McGregor, 1981).

(4) Late Archaean granitic activity in other areas of the North Atlantic craton. Late Archaean, post-granulite facies granitic rocks are widespread in the North Atlantic craton and are commonly associated with deformation. In some parts of the craton, for example the Hopedale area of Labrador (Ermanovics et al., 1982) and south-east Greenland (Andrews et al., 1973) syntectonic granite injection resulted in the formation of complex agmatites in which inclusions of older rocks are broken up and enclosed in a leucocratic matrix produced mainly by partial melting of earlier sialic material. In other areas, for example Saglek in northern Labrador, post-granulite facies granites, granodiorites and trondhjemites form major swarms of syntectonic sheets breaking up the older gneiss complex (Bridgwater $e t$ al., 1975, 1978, fig. 13 and unpublished). This late Archaean granitic sheeting intrudes and retrogresses regional granulites dated by U-Pb on zircon at $2825 \mathrm{Ma}$ (Morgan, 1979) and is cut by post-tectonic granites dated at $2520 \mathrm{Ma}$ (Baadsgaard et al., 1979). A Rb-Sr age of $2825{ }_{-158}^{+198} \mathrm{Ma}$ is reported for part of this activity from Saglek in Labrador by Collerson $\mathrm{et}$ al. (1982) and these writers have correlated the sheets with the Nûk gneisses of West Greenland. The absence of a unit in the Saglek area corresponding in regional setting or geochemistry to the Godthåbsfjord Nûk gneisses reinforces our contention that the post-granulite facies magmatism in the two areas should be regarded as a totally separate phenomenon and no longer treated as a broad continuation of Nûk magmatism.

\section{Chemistry and petrology}

Most Qârusuk dykes have more than $70 \mathrm{wt} \% \mathrm{SiO}_{2}$. They have low $\mathrm{FeO}^{\mathrm{t}}+\mathrm{MgO}$, but high $\mathrm{Na}_{2} \mathrm{O}+\mathrm{K}_{2} \mathrm{O}$. Over half of the analysed samples have $\mathrm{Na}_{2} \mathrm{O} / \mathrm{K}_{2} \mathrm{O}$ values between 0.6 and 1.0. The rest are more sodic, with $\mathrm{Na}_{2} \mathrm{O} / \mathrm{K}_{2} \mathrm{O}$ values of up to 22 . Mineralogically they are fairly simple rocks with microcline, sodic plagioclace, quartz and both muscovite and biotite. The total mafic content is low. Allanite, epidote and zircon are the commonest accessories.

In a salic tetrahedron (fig. 1) the more abundant granitic (lower $\mathrm{Na}_{2} \mathrm{O} / \mathrm{K}_{2} \mathrm{O}$ ) samples fall close to the plagioclase-potash feldspar-quartz join with $\mathrm{P}_{\mathrm{H2O}}=7 \mathrm{~kb}$; i.e. within the field of low temperature melt compositions in the system. The sodic Qârusuk dyke samples scatter away from the field of low temperature melt compositions.

The $\mathrm{Na}_{2} \mathrm{O} / \mathrm{K}_{2} \mathrm{O}$ variation from dyke to dyke and within single dykes is attributed to $\mathrm{Na}-\mathrm{K}$ exchange between originally granitic dyke material and a percolating fluid phase, leading to localised, irregular, but in some cases extreme $\mathrm{Na}_{2} \mathrm{O}$ enrichment and $\mathrm{K}_{2} \mathrm{O}$ loss (see samples 243064 A \& B, Table 2). Non-magmatic controls of element distribution and interaction 
Fig. 1. Qârusuk (mesonorms) within the salic tetrahedron. *Trondhjemite here defined as rocks with $\mathrm{Na} / \mathrm{K}>2$.

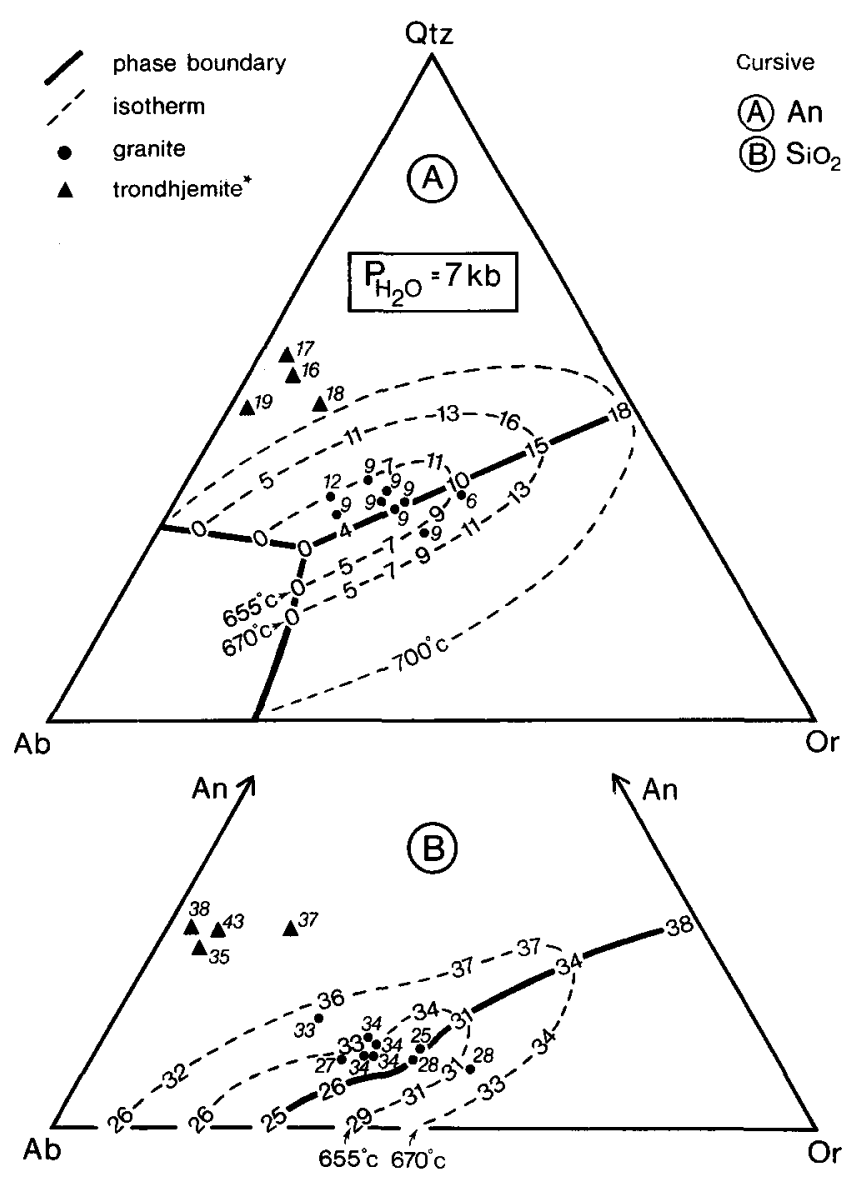

with wall rocks can also explain the highly variable trace element compositions, particularly those elements which are soluble in alkaline solutions; $\mathrm{Rb}, \mathrm{Ba}, \mathrm{Pb}$ and $\mathrm{U}$ contents are high in general compared with Amîtsoq and Nûk gneisses while $\mathrm{Sr}$ is low. In many respects the trace element distributions in these dykes resemble that seen in shear zones along which there has been fluid transport (Bridgwater, 1979). Isotopic evidence for interaction between the Qârusuk dykes and fluids is discussed later.

There is no rare earth element (REE) data published for the type Qârusuk dykes. Compton (1978) presented data for late sheets (specimens 205759, 175766, 174816, 205854, $205008,204967)$ that are correlated by us with the Qârusuk dykes. These late sheets have steep REE patterns with small, generally negative Eu anomalies are extremely enriched in light REE and have chondrite normalised $\mathrm{La} / \mathrm{Yb}$ values of over 100. Compton (1978) suggested that the REE chemistry of these rocks is controlled by garnet. However, as at least some of these sheets occur in shears where is evidence of fluid movement, their chemistry need not be solely controlled by magmatic processes and thus the REE data like the $\mathrm{Sr}$ isotope data should be interpreted with caution. 
Table 2. Selected analyses of Qârusuk dykes

\begin{tabular}{|c|c|c|c|c|c|c|c|c|c|c|c|}
\hline & 152773 & 163273 & 152759 & 152760 & 152761 & $243064 \mathrm{~A}$ & $243064 \mathrm{~B}$ & 248060 & $243030 \mathrm{~A}$ & $243030 \mathrm{~B}$ & 248083 \\
\hline $\mathrm{SiO}_{2}$ & 73.43 & 71.37 & 67.88 & 75.50 & 71.59 & 73.79 & 72,43 & 73.08 & 72.26 & 72.39 & 74.65 \\
\hline $\mathrm{TiO}_{2}$ & 0.18 & 0.33 & 0.41 & 0.17 & 0.20 & 0.24 & 0.17 & 0.14 & 0.16 & 0.19 & 0.10 \\
\hline $\mathrm{Al}_{2} \mathrm{O}_{3}$ & 13.54 & 14.74 & $16 \cdot 32$ & 13.78 & 14.81 & 13.40 & 13.48 & 14.66 & 14.39 & 14.46 & 13.60 \\
\hline $\mathrm{Pe}_{2} \mathrm{O}_{3}$ & $1.50^{*}$ & 0.25 & 1.02 & 0.34 & 0.24 & 0.73 & 0.50 & 0.13 & 0.37 & 0.36 & 0.96 \\
\hline $\mathrm{FeO}$ & - & 1.64 & 1.80 & 0.60 & 1.27 & 1.11 & 1.23 & 1.10 & 1.30 & 1.29 & 0.15 \\
\hline MnO & 0.04 & 0.02 & - & - & - & 0.01 & 0.02 & 0.03 & 0.02 & 0.01 & 0.04 \\
\hline $\mathrm{MgO}$ & 0.09 & 0.47 & 1.00 & 0.36 & 0.45 & 0.23 & 0.13 & 0.59 & 0.36 & 0.35 & 0.22 \\
\hline $\mathrm{CaO}$ & 1.03 & 1.80 & 3.19 & 3.02 & 1.65 & 1.35 & 1.15 & 3.30 & 1.59 & 1.64 & 1.18 \\
\hline $\mathrm{Na}_{2} \mathrm{O}$ & 3.68 & 4.14 & 3.91 & 3.82 & 3.50 & 8.14 & 4.19 & 4.64 & 3.26 & 3.24 & 4.97 \\
\hline $\mathrm{K}_{2} \mathrm{O}$ & 4.95 & $4 \cdot 12$ & 2.19 & 0.94 & 5.19 & 0.36 & 4.83 & 0.73 & 5.14 & 5.05 & 1.94 \\
\hline $\mathrm{P}_{2} \mathrm{O}_{5}$ & 0.04 & 0.13 & 0.09 & 0.02 & 0.05 & 0.07 & 0.05 & 0.03 & 0.07 & 0.07 & 0.02 \\
\hline \multirow[t]{3}{*}{1.0 .1} & 1.25 & 0.47 & 1.12 & 0.60 & 0.61 & 0.56 & 1.57 & 0.60 & 0.43 & 0.19 & 1.21 \\
\hline & 99.73 & 99.48 & 98.93 & 99.15 & 99.56 & 99.99 & 99.75 & 99.03 & 99.35 & 99.24 & 99.04 \\
\hline & * total & as $\mathrm{Fe}_{2} \mathrm{O}_{3}$ & 1.0.1. corr & ed for & in GGU a & yses & & & & & \\
\hline $\mathrm{Rb}$ & 233 & & & & & & & 25 & 129 & 130 & 121 \\
\hline Sr & 99 & & & & & & & 161 & 183 & 182 & 162 \\
\hline $\mathrm{Ba}$ & 518 & & & & & & & 117 & 1415 & 1436 & 287 \\
\hline$Y$ & 6 & & & & & & & 8 & 9 & 10 & 10 \\
\hline $\mathrm{Zr}$ & 139 & & & & & & & 124 & 211 & 223 & 129 \\
\hline $\mathrm{Pb}$ & 35 & & & & & & & 8 & 33 & 33 & 112 \\
\hline $\mathrm{Nb}$ & 10 & & & & & & & 8 & 5 & 3 & 14 \\
\hline $\mathrm{Cr}$ & 6 & & & & & & & 8 & - & - & 5 \\
\hline Co & 1 & & & & & & & 9 & - & 0 & 5 \\
\hline $\mathrm{Ni}$ & 0 & & & & & & & 18 & 1 & 0 & 36 \\
\hline $\mathrm{Cl}$ & 121 & & & & & & & - & 175 & 199 & - \\
\hline u & - & & & & & & & 0.585 & 0.76 & 1.77 & 2.74 \\
\hline Th & 19 & & & & & & & - & 36 & 32 & - \\
\hline
\end{tabular}

163273, 152773. Qingordlit, south coast of Bjornegen, 152773 sample dated by U-Pb. $243064 A+B, 248083$. Qârusuk, south cosst of Bjømeren.

243030A, 243034B. Flat-lying sheet, southern part of Kangimut sangmissoq. Major elements GGJ, except 152773.

(P. Harvey, Nottingham University). Minor elements, P. Harvey. Uranium, Risø National Laboratory. 
The overall geochemical character of the Qârusuk dykes suggests that they originated from granitic, low temperature partial melts of sialic crustal rocks. These were emplaced as dykes, commonly along active shear zones, and they were altered by fluids migrating along them

\section{Isotope chemistry}

Qârusuk dykes and equivalent rocks differ considerably in their isotope chemistry from the type Nûk gneisses. Three Qârusuk dykes $(86523,86536,86550)$ and two gneisses from inner Godthåbsfjord with chemistry similar to the Qârusuk dykes $(131502,131503)$ were included in the sample set of Nûk gneisses considered by Moorbath \& Pankhurst (1976) and Taylor et al. (1980). Taylor et al. (1980, table 1) derived a function, ${ }^{204} \mathrm{~Pb}_{\mathrm{c}}{ }^{204} \mathrm{~Pb}_{\mathrm{t}}$, for the proportion of contaminant Amîtsoq-type $\mathrm{Pb}$ to total $\mathrm{Pb}$, assuming a uniform Amîtsoq $\mathrm{Pb}$ source with an average compostion equal to that of the Oxford collection of Amitsoq gneisses and an age of $2850 \mathrm{Ma}$. None of the type Nûk gneisses have ${ }^{204} \mathrm{~Pb}_{\mathrm{c}}{ }^{204} \mathrm{~Pb}_{\mathfrak{t}}$ ratios of more than 0.40 . All the specimens with ratios greater than this are known or suspected to be Qârusuk dykes or have granitic (s.s.) compositions that are not typical of the type Nûk gneisses. The use of these specimens in discussions of the source of contamination of the lead in Nûk gneisses (Taylor et al., 1980, pp 1448-1450) can no longer be justified. However, the arguments that the high proportion of Amîtsoq-type $\mathrm{Pb}$ could be the result of partial melting of Amîtsoq gneisses or of zone refining and scavenging during migration of the melts and associated fluids through Amitsoq genisses can be applied to the Qârusuk dykes.

Qârusuk dykes are also characterised by high, but variable $\mathrm{Sr}_{\mathbf{0}}$ values. Roberts (1979) obtained a six-point $\mathrm{Rb} / \mathrm{Sr}$ whole-rock isochron of $2692 \pm 60 \mathrm{Ma}$ with $\mathrm{Sr}_{\mathrm{o}}$ of $0.7060 \pm$ 0.0015 on granitic dykes of Qârusuk type that cut an early Nûk tonalite in Ameralik. Similar dykes at Kangimut sangmissoq across Ameralik have given a four-point $\mathrm{Rb}$-Sr whole-rock isochron age of $2680 \pm 160 \mathrm{Ma}$ with $\mathrm{Sr}_{\mathrm{o}}$ of $0.7045 \pm 0.0010$ (S. Moorbath \& P. Taylor, personal communication). ${ }^{87} \mathrm{Sr} /{ }^{86} \mathrm{Sr}$ ratios at $2660 \mathrm{Ma}$ of Qârusuk dykes samples for which data were given by Moorbath \& Pankhurst (1976) are given in Table 3.

The isotopic data available at present are consistent with generation of the Qârusuk magmas by partial melting of older sialic rocks that included a significant component of Amîtsoq gneisses. Lack of correlation between $\mathrm{Sr}_{0}$ values for individual samples of suites

Table 3. Isotopic data from Qârusuk dykes and other post-Nûk gneisses in the Godthåbsfjord area

\begin{tabular}{|c|c|c|c|c|c|}
\hline & $\mathrm{Rb}$ & $\mathrm{Sr}$ & $\mathrm{Pb}$ & ${ }^{204} \mathrm{~Pb}_{\mathrm{C}}$ & $S r_{0}$ at \\
\hline & ppm & ppm & ppm & $204 \mathrm{~Pb}_{t}$ & $2660 \mathrm{Ma}$ \\
\hline 86523 & 150 & 200 & 47.3 & 0.68 & 0.7123 \\
\hline 86536 & 95 & 360 & 18.1 & 0.12 & 0.7045 \\
\hline 86550 & 150 & 220 & 41.7 & 0.62 & 0.7129 \\
\hline 131502 & 182 & 190 & 35.4 & 0.64 & 0.708 \\
\hline 131503 & 177 & 148 & 45.9 & 0.74 & $0.708^{*}$ \\
\hline
\end{tabular}


and the immediately surrounding rocks suggests that the source region was deeper in the crust. The variation in $\mathrm{Sr}_{0}$ may reflect differences in source material or difference in the amounts of $\mathrm{Sr}$ scavenged from the country rocks or introduced by circulating fluids.

\section{Conclusions}

The Qârusuk dykes are the products of partial melting of sialic crustal rocks in the period between the c. $2800 \mathrm{Ma}$ granulite facies metamorphism and the intrusion of the essentially post-tectonic Qôrqut granite complex. They are geochemically quite distinct from the type Nûk gneisses and were separated from them in time by the granulite facies metamorphism.

The Qârusuk magmas were commonly intruded into active shear fractures. Many aspects of their geochemistry, e.g. high variable alkali contents, very variable trace element chemistry and incorporation of $\mathrm{Pb}$ and $\mathrm{Sr}$ derived from older crustal rocks, can be attributed to interaction with fluids that migrated along the same fractures.

The Qârusuk dykes were intruded during a period when the North Atlantic craton was affected by processes associated with migration of $\mathrm{H}_{2} \mathrm{O}$-rich fluids in the crust. These included very widespread retrogression of granulite facies mineral assemblages and the formation of linear belts of intense ductile deformation.

\section{References}

Andersen, L. S. \& Friend, C. 1973: Structure of the Ravns Storø amphibolite belt in the Fiskenæsset region. Rapp. Grønlands geol. Unders. 51, 37-40.

Andrews, J. R., Bridgwater, D., Gormsen, K., Gulson, K., Keto, L. \& Waterson, J. 1973: The Precambrian of South-East Greenland. In Park, R. G. \& Tarney, J. (edit.) The early Precambrian of Scotland and related rocks of Greenland, 143-156. Birmingham U.P.

Baadsgaard, H. 1976: Further U-Pb dates on zircons from the early Precambrian rocks of the Godthaabsfjord area, West Greenland. Earth planet. Sci. Lett. 33, 261-267.

Baadsgaard, H., Collerson, K. D. \& Bridgwater, D. 1979: The Archaean gneiss complex of northern Labrador. 1. Preliminary U-Th-Pb geochronology. Can. J. Earth Sci. 16, 951-961.

Baadsgaard, H. \& McGregor, V.R. 1981: The U-Th-Pb systematics of zircons from the type Nûk gneisses, Godthåbsfjord, West Greenland. Geochim. cosmoshim. Acta. 45, 1099-1109.

Berthelsen, A. 1960: Structural studies in the pre-Cambrian of western Greenland. II. Geology of Tovqussap nunâ. Bull. Grønlands geol. Unders. 25 (also Meddr Grønland 123,1) 223 pp.

Black, L.P., Moorbath, S., Pankhurst, R. J. \& Windley, B.F. 1973: ${ }^{207} \mathrm{~Pb} /{ }^{206} \mathrm{~Pb}$ whole rock age of Archaean granulite facies metamorphic event in West Greenland. Nature Phys. Sci. 244, 50-53.

Brewer, M., Coe, K. \& Robertson, S. 1983: Continuation of the mapping of Archaean rocks in the southern part of the Ivisârtoq map sheet. Rapp. Grønlands geol. Unders. 115, 42-48.

Bridgwater, D. 1979: Chemical and isotopic redistribution in zones of ductile deformation in a deeply eroded mobile belt. Part 1. Chemical redistribution. U.S. geol. Surv. open file rep. 79-1239, 505-526.

Bridgwater, D., Collerson, K. D., Hurst, R. W. \& Jesseau, C. W. 1975: Field characteristics of the early Precambrian rocks from Saglek, coast of Labrador, Geol. Surv. Can. Pap. 75-1A, 287-296.

Bridgwater, D., Collerson, K. D. \& Myers, J. S. 1978: The development of the Archaean gneiss complex of the North Atlantic region. In Tarling. D.H. (edit.) Evolution of the Earth's crust, 123-145. London: Academic Press. 
Bridgwater, D., Keto, L., McGregor, V.R. \& Myers, J.S. 1976: Archaean gneiss complex of Greenland. In Escher, A \& Watt, W.S. (edit.) Geology of Greenland, 18-75. Copenhagen: Geol. Surv. Greenland.

Bridgwater, D., McGregor, V.R. \& Myers, J. S. 1974: A horizontal tectonic regime in the Archaean of Greenland and its implication for crustal thickening. Precambrian Res. 1, 179-197.

Brown, M., Friend, C.R.L., McGregor, V.R. \& Perkins, W.T. 1981: The late Archaean Qôrqut granite complex of southern West Greenland. J. geophys. Res. 86, 10617-10632.

Coe, K. \& Robertson, S. 1982: Mapping of Archaean rocks in part of the Ivisârtoq sheet. Rapp. Grønlands geol. Unders. 110, 63-67.

Collerson, K. D., Kerr, A., Vocke, R. D. \& Hanson, G. N. 1982: Reworking of sialic crust as represented in late Archean-age gneisses, northern Labrador. Geology 10, 202-208.

Compton, P.M. 1978: Rare earth evidence for the origin of the Nûk gneisses, Buksefjord region, southern West Greenland. Contr. Mineral Petrol. 66, 283-293.

Dymek, R.F. 1978: Metamorphism of the Archaean Malene supracrustals, Godthåb district, West Greenland. Abstr. 1978 Archaean Geochem. Field Conf., Ontario.

Ermanovics, I.F., Korstgård, J.A. \& Bridgwater, D. 1982: Structural and lithological chronology of the Archean Hopedale block and the adjacent Proterozoic Makkovik subprovince, Labrador Report 4, Geol. Surv. Can. Pap. 82-1b, 153-165.

James, P.R. 1975: Field mapping of Bjørneøen and the adjacent coast of Nordlandet, Godthåbsfjord, southern West Greenland. Rapp. Grønlands geol. Unders. 75, 58-62.

Kalsbeek, F. \& Myers, J. S. 1973: The geology of the Fiskenæsset region. Rapp. Grønlands geol. Unders. 51, 5-18.

Karlsbeek, F. \& Pidgeon, R.T. 1980: The geological significance of Rb-Sr whole-rock irochrons of polymetamorphic Archaean gneisses, Fiskenæsset area, southern West Greenland. Earth planet. Sci. Lett. 50, 225-237.

McGregor, V.R. 1973: The early Precambrian gneisses of the Godthåb district, West Greenland. Phil. Trans. R. Soc. Lond. A, 273, 343-358.

McGregor, V.R. 1979: Archaean gray gneisses and the origin of the continental crust: evidence from the Godthåb region, West Greenland. In Barker, F. (edit.). Trondhjemites, dacites and related rocks, 169-204. Amsterdam: Elsevier.

Moorbath, S. \& Pankhurst, R. J. 1976: Further rubidium-strontium age and isotope evidence for the nature of the late Archaean plutonic event in West Greenland. Nature 262, 124-126.

Moorbath, S., Taylor, P. N. \& Goodwin, R. 1981: Origin of granitic magma by crustal remobilization: $\mathrm{Rb}-\mathrm{Sr}$ and $\mathrm{Pb} / \mathrm{Pb}$ geochronology and isotope geochemistry of the late Archaean Qôrqut Granite Complex of southern West Greenland. Geochim. cosmochim. Acta. 45, 1051-1060.

Morgan, W.C. 1979: Geology Nachvak Fiord - Ramah Bay, Newfoundland - Quebec. Geol. Surv. Canada Map 1469a.

Myers, J.S. 1973: Field evidence concerning the origin of early Precambrian gneisses and amphibolites in part of the Fiskenæsset region. Rapp. Grønlands geol. Unders. 51, 19-22.

Myers, J.S. 1976: Acid and intermediate intrusions, deformation and gneiss formation, north-east of Fiskenæsset. Rapp. Grønlands geol. Unders. 73, 7-15.

Nutman, A.P. 1982: Investigation on amphibolite facies orthogneisses, amphibolites and leucogabbros on Akugdlerssuaq, inner Godthåbsfjord. Rapp. Grønlands geol. Unders. 110, 72-77.

Pankhurst, R.J., Moorbath, S. \& McGregor, V.R. 1973: Late event in the geological evolution of the Godthåb district, West Greenland. Nature Phys. Sci. 243, 24-26.

Pidgeon, R.T. \& Kalsbeek, F. 1978: Dating of igneous and metamorphic events in the Fiskenaesset region of southern West Greenland. Can. J. Earth Sci. 15, 2021-2025.

Roberts, I.W.N. 1979: Archaean evolution of inner Ameralik, south west Greenland, with special reference to mid-Archaean magmatism. Unpublished Ph.D. thesis, Univ. Wales, Aberystwyth. 
Robertson, S. 1983: The provisional results of isotope investigations into quartzo-feldspathic rocks from Kangiussap nunâ, Ivisârtoq sheet, southern West Greenland. Rapp. Grønlands geol. Unders. 115, 56-59.

Taylor, P.N., Moorbath, S., Goodwin, R. \& Petrykowski, A. 1980: Crustal contamination as an indicator of the extent of early Archaean crust: $\mathrm{Pb}$ isotopic evidence from the late Archaean gneisses of West Greenland. Geochim. cosmochim. Acta 44, 1437-1453. 